\title{
Repression of tumor necrosis factor-related apoptosis-inducing ligand (TRAIL) but not its receptors during oral cancer progression Nadarajah Vigneswaran*1, Darryl C Baucum ${ }^{1}$, Jean Wu${ }^{1}$, Yahuan Lou ${ }^{1}$, Jerry Bouquot ${ }^{1}$, Susan Muller ${ }^{2}$ and Wolfgang Zacharias ${ }^{3}$
}

\begin{abstract}
Address: ${ }^{1}$ Department of Diagnostic Sciences, The University of Texas Health Science Center at Houston, Dental Branch, Houston, Texas 77030, USA, ${ }^{2}$ Departments of Pathology and Otolaryngology-Head and Neck Surgery, Emory University School of Medicine, Atlanta, Georgia 30322, USA and ${ }^{3}$ Departments of Medicine, Pharmacology \& Toxicology, James Graham Brown Cancer Center, University of Louisville, Louisville, Kentucky 40202, USA

Email: Nadarajah Vigneswaran* - nadarajah.vigneswaran@uth.tmc.edu; Darryl C Baucum - darryl.c.baucum@uth.tmc.edu; JeanWu - jean.g.wu@uth.tmc.edu; Yahuan Lou - yahuan.lou@uth.tmc.edu; Jerry Bouquot - jerry.bouquot@uth.tmc.edu; Susan Muller - smuller@emoryhealthcare.org; Wolfgang Zacharias -w0zach01@gwise.louisville.edu

* Corresponding author
\end{abstract}

Published: 25 June 2007

BMC Cancer 2007, 7:108 doi:10.1 186/147|-2407-7-108
Received: 27 February 2007

Accepted: 25 June 2007

This article is available from: http://www.biomedcentral.com/I47/-2407/7//08

(C) 2007 Vigneswaran et al; licensee BioMed Central Ltd.

This is an Open Access article distributed under the terms of the Creative Commons Attribution License (http://creativecommons.org/licenses/by/2.0), which permits unrestricted use, distribution, and reproduction in any medium, provided the original work is properly cited.

\begin{abstract}
Background: TRAIL plays an important role in host immunosurveillance against tumor progression, as it induces apoptosis of tumor cells but not normal cells, and thus has great therapeutic potential for cancer treatment. TRAIL binds to two cell-death-inducing (DR4 and DR5) and two decoy (DcRI, and DcR2) receptors. Here, we compare the expression levels of TRAIL and its receptors in normal oral mucosa (NOM), oral premalignancies (OPM), and primary and metastatic oral squamous cell carcinomas (OSCC) in order to characterize the changes in their expression patterns during OSCC initiation and progression.

Methods: DNA microarray, immunoblotting and immunohistochemical analyses were used to examine the expression levels of TRAIL and its receptors in oral epithelial cell lines and in archival tissues of NOM, OPM, primary and metastatic OSCC. Apoptotic rates of tumor cells and tumor-infiltrating lymphocytes (TIL) in OSCC specimens were determined by cleaved caspase 3 immunohistochemistry.

Results: Normal oral epithelia constitutively expressed TRAIL, but expression was progressively lost in OPM and OSCC. Reduction in DcR2 expression levels was noted frequently in OPM and OSCC compared to respective patient-matched uninvolved oral mucosa. OSCC frequently expressed DR4, DR5 and DcR I but less frequently DcR2. Expression levels of DR4, DR5 and DcRI receptors were not significantly altered in OPM, primary OSCC and metastatic OSCC compared to patient-matched normal oral mucosa. Expression of proapoptotic TRAIL-receptors DR4 and DR5 in OSCC seemed to depend, at least in part, on whether or not these receptors were expressed in their parental oral epithelia. High DR5 expression in primary OSCC correlated significantly with larger tumor size. There was no significant association between TRAIL-R expression and OSSC histology grade, nodal status or apoptosis rates of tumor cells and TIL.

Conclusion: Loss of TRAIL expression is an early event during oral carcinogenesis and may be involved in dysregulation of apoptosis and contribute to the molecular carcinogenesis of OSCC. Differential expressions of TRAIL receptors in OSCC do not appear to play a crucial role in their apoptotic rate or metastatic progression.
\end{abstract}




\section{Background}

TRAIL (tumor necrosis factor-related apoptosis-inducing ligand; Apo2L) is a type II transmembrane protein which selectively induces apoptosis in tumor cells but not normal cells $[1,2]$. Because of this differential sensitivity TRAIL is considered an ideal anticancer drug [3,4]. It interacts with four distinct surface receptors, TRAIL-R1 (DR4), -R2 (DR5), -R3 (DcR1), and R4 (DcR2) and with the soluble receptor osteoprotegerin $[1,2]$. DR4 and DR5 act as transmembrane signaling death receptors with cytoplasmic death domains (DD) which respond to ligand binding and activate the extrinsic cell death pathway by facilitating interaction between the specific adapter protein (FAS-associated DD) and proapoptotic effector proteins (caspases 8 and 10) [5]. DcR1 and DcR2 (decoy receptors), conversely, cannot mediate apoptosis because they lack functional DD [6]. It has been suggested that the differences in the expression levels of death (DR4 and DR5) versus decoy (DcR1 and DcR2) receptors can determine the sensitivity of tumor cells to TRAIL-induced apoptosis [6]. However, susceptibility to TRAIL-induced apoptosis does not always correlate well with the cell surface expression levels of death-inducing and decoy TRAIL receptors suggesting a regulatory role for downstream signaling and effector molecules $[7,8]$. Furthermore, recent studies indicate that TRAIL susceptibility of tumors in vivo is modified by tumor microenvironmental factors and tumor hypoxia $[9,10]$.

Recombinant TRAIL protein (rTRAIL) induces significant tumor regression in mice bearing human tumor xenografts without producing any serious systemic effects in the host $[11,12]$. Importantly, radiation and certain chemotherapeutic drugs increase the susceptibility of tumor cells to rTRAIL and agonistic TRAIL-R antibodies [13-17]. Hence, combinations of rTRAIL + chemotherapy or TRAIL + radiation produce synergistic anti-tumor effects both in vitro and in mice bearing human tumor xenografts [18]. Human rTRAIL (PRO1762) and monoclonal antibodies that induce trimerization of DR4 (HGSETR 1) and DR5 (HGS-ETR 2) are currently undergoing phase Ib and II clinical evaluations, respectively [19]. Moreover, use of DR4 (HGS-ETR1) agonist antibody as a single agent or in combination with chemotherapy has been shown to stabilize disease in patients with advanced head and neck cancer [20]. In addition to its therapeutic potential, endogenously expressed TRAIL is an effector molecule important for the host's antitumor immune response $[2,21,22]$.

Despite various treatment approaches, most patients with advanced oral squamous cell carcinomas (OSCC) develop local or regional recurrences (50-60\%) and metastatic disease ( $20 \%$ ) leading to poor survival rate. Therefore, there is an unmet need for more efficacious and less toxic molecularly targeted therapies for treating OSCC. Recent preclinical and clinical data have shown the potential utility of TRAIL-R targeted therapies in advanced cancers, including OSCC $[4,19,23]$. Currently, there are only limited data available pertaining to the baseline expression levels of TRAIL and its receptors in normal oral mucosa, oral premalignancies (OPM) and primary or metastatic oral squamous cell carcinoma (OSCC) $[24,25]$. These data are critical to analysis and interpretation of clinical trial data involving rTRAIL and TRAIL receptor agonist antibodies in OSCC patients, as well as the understanding of the role of TRAIL and its receptors during oral carcinogenesis. In the present study we determined changes in the expression of TRAIL and TRAIL-R during OSCC development and progression by comparing expression patterns in normal oral mucosa (NOM), oral premalignancies (OPM), primary OSCC and metastatic OSCC. We also correlated the expression levels of TRAIL-receptor in OSCC with various clinicopathologic prognosticators. Finally we correlated the apoptosis rate of tumor cells and tumor-infiltrating lymphocytes (TIL) in OSCC with their respective TRAIL and TRAIL-R expression patterns.

\section{Methods \\ Cell lines and human tissue}

Normal human oral mucosal epithelia cells (NOM) were established from discarded human gingival tissue. NOM cells within their first two serial passages in culture were used for RNA isolation and cellular protein extraction. Details related to OPM (Leuk1 \& Leuk2), primary OSCC (686Tu, 1386Tu and 101A) and metastatic OSCC (686Ln and $1386 \mathrm{Ln}$ ) cell lines have been described previously [7,26-28]. HOK-16B is a normal oral keratinocyte-derived cell line immortalized by transfection with HPV-16 genome [29]. Chronic exposure of HOK-16B cells with benzo $(a)$ pyrene produced the tumorigenic HOK-16BBap-T cell line [29]. NOM, Leuk1, Leuk2 and HOK-16B cells were grown in keratinocyte growth media (KGM-2) supplemented with growth factor Bullit kit (Cambrex, East Rutherford, NJ, USA). HOK-16B-BaP-T and OSCC cell lines were maintained in DMEM/F12 50/50 mix (Cambrex) containing 10\% fetal bovine serum, $0.4 \mu \mathrm{g} / \mathrm{ml}$ hydrocortisone, and penicillin-streptomycin-amphotericin antibiotic mix.

Archival tissue specimens from primary OSCC $(\mathrm{n}=45)$ and corresponding lymph node metastases $(n=11)$ were used for light microscopic and immunohistochemical studies (Table 1). Oral leukoplakias with moderate to severe dysplasia $(\mathrm{n}=25)$ were used as OPM specimens. Five $\mu \mathrm{m}$ serial sections were cut from each specimen and processed for $H \& E$ and immunohistochemical staining. The histological grading of OPM and OSCC was determined by two pathologists using H\&E stained sections according to published criteria [30]. All tissue specimens 
Table I: Clinical data of the OSCC specimens used in this study

\begin{tabular}{lc}
\hline Parameter & No of cases (\%) \\
\hline Median age: 42 Y & $42(100)$ \\
Age range (years): $37-8 I$ Y & \\
Sex & \\
Male & $29(69)$ \\
Female & $13(31)$ \\
\hline Site & \\
Buccal mucosa & $2(5)$ \\
Tonsillar area & $7(17)$ \\
Retromolar pad & $3(7)$ \\
Gingiva & $2(5)$ \\
Floor of the mouth & $8(19)$ \\
Tongue & $15(36)$ \\
Unknown & $5(11)$ \\
\end{tabular}

and appropriate clinical information were obtained under the guidelines and approval of the Institutional Review Boards of The University of Texas Health Science Center at Houston.

\section{Microarray data sets}

We interrogated the expression levels of TRAIL and its receptors in our pre-existing microarray data sets on the above oral cell lines representing different phenotypes. Relative RNA expression levels were determined using Affymetrix U133A oligonucleotide microarrays $(33,000$ annotated genes) as described $[27,28]$. Either two or four biological replicate experiments were done independently by two different investigators. The U133A array included three different probe sets for TRAIL (NM_003810), DR5 (TRAIL-R2; NM_003842) and DcR1 (TRAIL-R3; NM_003841) and one probe set for DCR2 (TRAIL-R4; NM_003840), but no probe sets for TRAIL receptor DR4 (TRAIL-R1; NM_003844). Signal intensity for each gene was calculated using the Affymetrix MAS 5.0 probe level algorithm. Phenotypic-specific gene expression values for TRAIL, DR5, DcR1 and DcR2 genes were calculated by averaging signal intensities across sample replicates for cell lines belonging to each phenotypic group.

\section{Western blotting for TRAIL protein}

TRAIL protein levels were examined by Western blotting in cell extracts of NOM cells from two different patients (NOM-1 \& 2), OPM cell line Leuk1, and from primary (1386Tu) and metastatic (1386Ln) OSCC cell lines. These cellular extracts were separated by $12 \%$ SDS-PAGE and transferred to nitrocellulose membrane (Novex, San Diego, CA). The membranes were incubated in blocking solution (5\% milk powder in $10 \mathrm{mM}$ TRIS-HCl, $\mathrm{pH} 8.0$, $150 \mathrm{mM} \mathrm{NaCl}, 0.1 \%$ Tween 20 ) at room temperature for $1 \mathrm{~h}$, then immunoblotted with polyclonal goat antihuman TRAIL (1: 200, Santa Cruz Biotechnology, CA,
USA) or monoclonal mouse anti- $\beta$ actin (Sigma-Aldrich $\mathrm{Co}$, St. Louis, MO) antibody followed by horseradish peroxidase-conjugated secondary antibody and chemiluminescence detection.

\section{Immunohistochemistry}

We investigated TRAIL and its receptor expression by semiquantitative immunohistochemistry in 25 OPMs (leukoplakias with moderate to severe dysplasia) and in 45 primary OSCCs and 9 patient-matched metastatic OSCCs. Tissue sections were deparaffinized, rehydrated, and subjected to antigen retrieval by heating in target antigen retrieval solution (DakoCytomation, Carpinteria, CA, USA) according to the manufacturer's protocol. Polyclonal antibodies against human TRAIL (goat anti-TRAIL, Santa Cruz, CA. USA; 1:40), DR4 (goat anti-DR4, Santa Cruz, CA., USA; 1:50), DR5 (rabbit anti-DR5, Oncogene, CA., USA; 1:100), DcR1 (rabbit anti-DcR1, Oncogene, CA, USA; 1:50) and DcR2 (rabbit anti-DcR1, Oncogene, CA, USA; $1: 25)$ were used for immunohistochemical detection. Apoptotic rates of OSCC cells and tumor-infiltrating lymphocytes (TIL) were determined by immunohistochemical detection of cleaved caspase 3 (Rabbit anticleaved caspase 3, Cell Signaling, CA, USA, 1:50) [31]. Immunoreactive sites were visualized using the standard Streptavidin-Biotin-HRP detection method, using diaminobenzidine tetrachloride as chromogenic substrate.

\section{Pathological and immunohistochemical evaluations}

Immunoreactive patterns of TRAIL and its receptors were compared with uninvolved mucosa adjacent to the epithelial dysplasias and invasive tumors. Expression levels of TRAIL and its receptors were evaluated semiquantitatively by two independent examiners as described [32]. A score from 0 (no staining) to 4 (strong immunoreactivity) was assigned to staining intensity, and the percentage of positive cells for each staining intensity in tumors and dysplastic areas of leukoplakias was determined. Immunoreactive scores (range $0-4$ ) were calculated by multiplying percentage of positive cells times staining intensity score. Cleaved caspase- 3 positive tumor cells and TIL in randomly selected five to seven high-power $(200 \times)$ fields (HPF) across the tumor section were counted using Image Pro Plus V (Media Cybernetics, Silver Spring, MD, USA). Caspase 3 labeling index $\left(\mathrm{LI}_{\text {Casp }}\right)$ for each tumor is expressed as average \# positive cells/HPF.

\section{Statistical analysis}

Two-sample t-test and one-way ANOVA were used to determine the statistical significance of the differences in TRAIL and its receptors expression levels in OPM and OSCC with various clinicopathologic parameters. Pearson's correlation was used to test the relationship between TRAIL-R expression patterns of uninvolved oral mucosa, and primary and metastatic tumor from the same patient. 


\section{Results}

TRAIL, DR5, DcRI and DcR2 RNA expression levels in normal, premalignant and malignant oral epithelial cells in vitro

TRAIL mRNA was detectable in all samples; however its expression level was significantly $(\mathrm{p} \leq 0.001)$ higher in NOM cells (mean $\pm \mathrm{SD}=364.9 \pm 20.4$ ) compared to immortalized oral epithelia (HOK-16B; mean \pm SD $=23.3$ \pm 10.6 ), OPM (Leuk1 and Leuk 2 cells mean $\pm \mathrm{SD}=48.2$ $\pm 20.1)$, malignant primary $(686 \mathrm{Tu}, 1386 \mathrm{Tu}, \mathrm{HOK}-16 \mathrm{~B}-$ Bap-Tu \&101A; mean $\pm \mathrm{SD}=25.3 \pm 11.3)$ and metastatic (686Ln and $1386 \mathrm{Ln}$; mean $\pm \mathrm{SD}=32.5 \pm 4.8$ ) oral epithelial cells (Figure 1). Among the TRAIL receptors, DR5 mRNA was consistently higher ( $>5$-fold) in all cell lines compared to low mRNA levels of DcR1 and DcR2 (Figure 2). DR4 expression levels were not available in our microarray database. There were no significant differences in the expression levels of all three TRAIL receptors among normal, immortalized, premalignant, and malignant primary and metastatic oral epithelial cells (Figure 2). Western blotting analysis showed that TRAIL protein is detectable as a $24 \mathrm{kD}$ band only in NOM cells but not in OPM and OSCC cells (Figure 3). We previously reported that expression of DR4, DR5, DcR1 and DcR2 proteins in primary and metastatic OSCC cells were not significantly different [7].

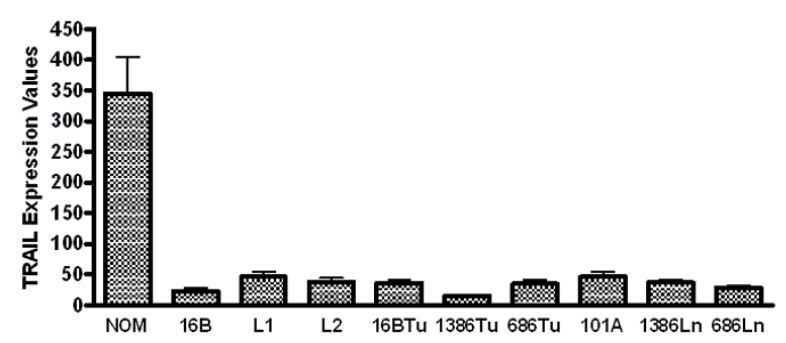

\section{Figure I}

TRAIL mRNA levels are markedly higher in normal oral epithelial cells (NOM) in comparison to immortalized (I6B), premalignant ( $\mathrm{LI}$ and $\mathrm{L2}$ ) and malignant oral epithelial cells (I6BTu, I386Tu, 686Tu, I0IA, I386Ln and 686Ln). Relative RNA expression levels of TRAIL were determined using Affymetrix UI33A oligonucleotide microarrays. Signal intensity for TRAIL was calculated using the Affymetrix MAS 5.0 probe level algorithm. NOM: Normal oral epithelial cells; I6B: Normal oral epithelial cells immortalized by HPV-I6 transfection (HOK-I6B). LI: OPM cell line MSK-LeukI; L2: OPM cell line MSK-Leuk2; I 6BTu: tumorigenic cell line derived from HOK-I6B; (HOK-I6B-Bap-T); I386Tu, 686Tu and I0IA: Cell lines derived from primary OSCC. I 386Ln and 686Ln: Cell lines derived from synchronous lymph node metastases of I386Tu and 686Tu tumors.

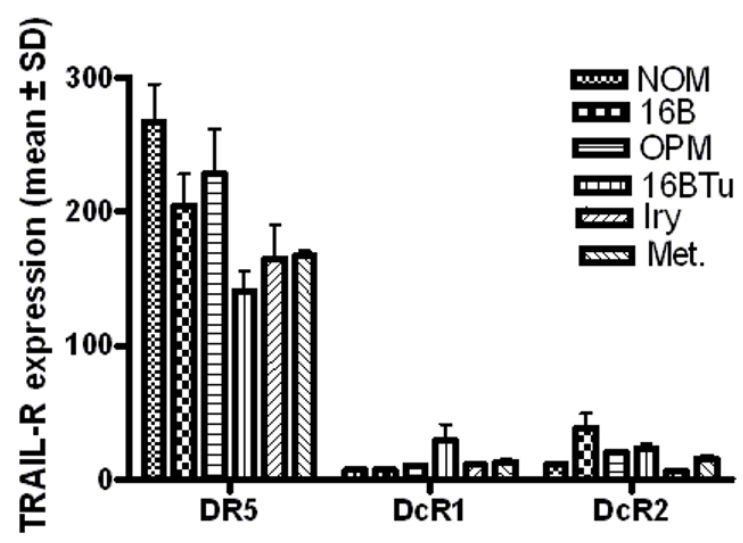

\section{Figure 2}

Expression levels of TRAIL-R, DR5, DcRI and DcR2 are not significantly different among normal (NOM), immortalized (I6B), premalignant (OPM), and malignant primary (Iry) and metastatic (Met) oral epithelial cells. Relative RNA expression levels of TRAIL-R were determined using Affymetrix UI33A oligonucleotide microarrays and their signal intensities were calculated using the Affymetrix MAS 5.0 probe level algorithm. Phenotypic-specific gene expression values for DR5, DcRI and DcR2 genes were calculated by averaging signal intensities across sample replicates for cell lines belonging to each phenotypic group. The mRNA levels of DR5 are significantly higher than the DcRI and DcR2 mRNA levels in these cell lines. The DNA microarray chips used in this study did not have the probe sets for DR4. NOM: Normal oral epithelial cells; I6B: Immortalized normal oral epithelial cells; OPM: Average target intensities of premalignant cell lines MSK-LeukI and MSK-Leuk2; I6BTu: tumorigenic cell line derived from HOK-I6B; Iry: Average target intensities of primary OSCC cell lines I386TU, 686Tu and I0IA. Met: Average target intensities of metastatic OSCC cell lines I386 Ln and 686Ln.

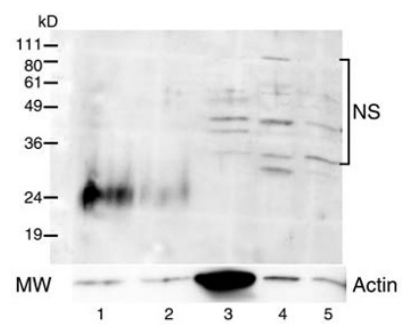

Figure 3

TRAIL protein is detectable only in normal oral epithelial cells (lanes I and 2) but not in premalignant (lane 3) and malignant oral epithelial cell lines (lanes 4 and 5). Total cellular proteins were extracted from two normal oral epithelial samples (NOM-I and 2-lanes I and 2), OPM cell line (MSK-Leuk I-lane 3), primary OSCC cell line (I 386Tulane 4) and metastatic OSCC cell line (I386Ln-lane 5) and analyzed for TRAIL protein by Western blotting. NS: none specific bands. 


\section{Expression of TRAIL and its receptors in OPM specimens} All OPM specimens (leukoplakias/erythroplakias with moderate to severe dysplasia) used in this study had normal oral mucosa (NOM) adjacent to the dysplasia. Of the 25 cases of oral leukoplakias with dysplasia, 56\% and $44 \%$ of them had moderate and severe dysplasia, respectively. Stratified squamous epithelium of the NOM exhibited membrane and cytoplasmic immunoreactivity for DR4, DR5, DcR1 and DcR2 (Figures 4, 5, 6, 7, 8, 9, 10). Cytoplasmic TRAIL protein was constitutively expressed by NOM (Figures 4, 5). Moreover, DR4, DR5 and DcR1 were expressed in all dysplastic oral epithelia (Figures 4,6, $7)$. On the other hand, TRAIL expression was lost in dysplasia compared to adjacent NOM (Figures 4, 5, 8). Staining intensity for DcR2 was also lower in dysplasia than in adjacent NOM (Figures 4 \&7).

\section{Expression of TRAIL and TRAIL-R in primary and metastatic OSCC specimens}

Forty-two primary OSCC and nine patient-matched cervical lymph node metastases, including NOM adjacent to the primary OSCC, were examined for TRAIL and TRAILR expression patterns (Table 1). Expression levels of each TRAIL-R in uninvolved oral mucosa adjacent to primary OSCC were determined and their Pearson correlation coefficient was calculated to be 0.898 for DR4, 0.863 for DR5 and 0.754 for DcR1 with a two-tailed $P$ value of $<$ 0.001 , indicating a strong correlation in their expression patterns between primary tumors and matched uninvolved oral mucosae. A similar correlation was not

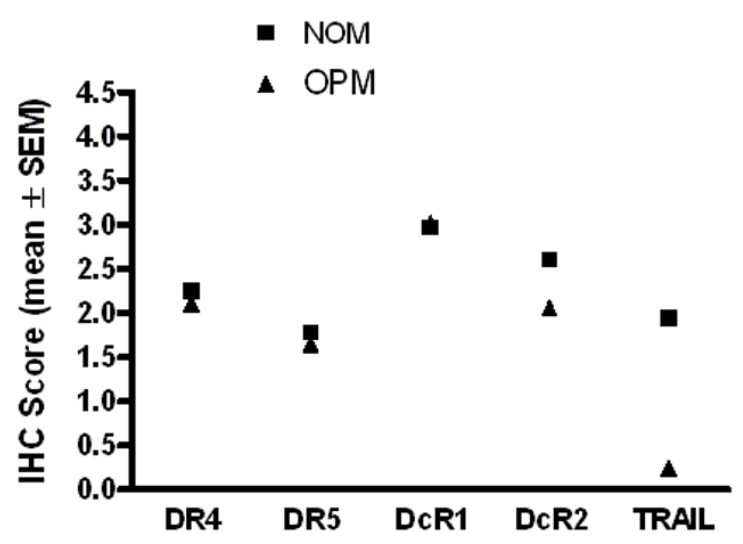

Figure 4

The expression levels of TRAIL and DcR2 are markedly reduced in oral premalignancy compared to normal oral mucosa. Graphic depiction of the mean expression levels of TRAIL and TRAIL-R in patient matched normal oral mucosa (NOM), oral premalignancies (OPM: leukoplakias with dysplasia). Mean expression levels of DR4, DR5 and DcRI did not differ significantly between normal oral mucosa (NOM) and oral premalignancies (OPM).

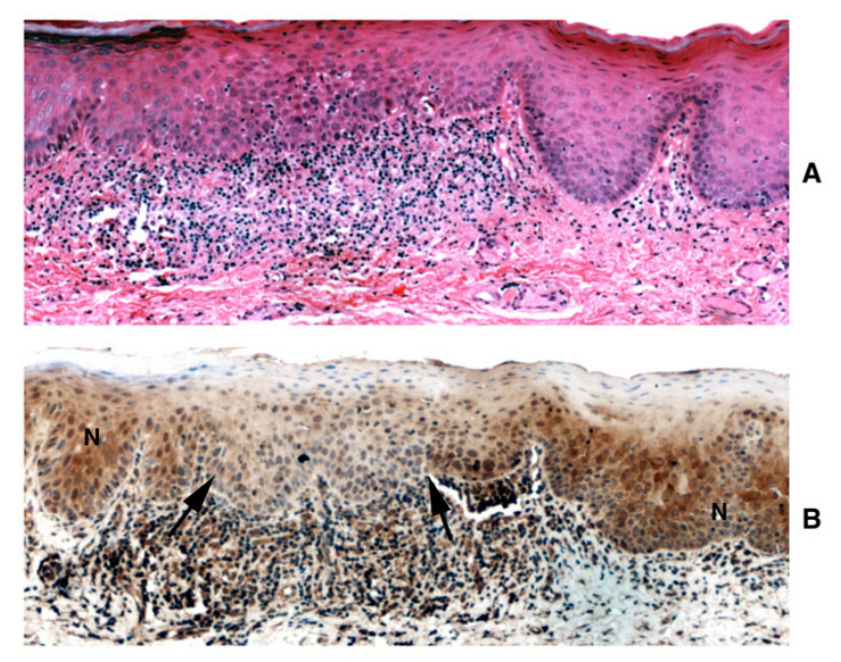

\section{Figure 5}

Loss of TRAIL expression in oral leukoplakia with moderate epithelial dysplasia. A: Hematoxylin and eosin staining; B: Immunohistochemical staining for TRAIL $(\times 100)$. Note that immunoreactivity for TRAIL is significantly reduced in dysplasia (arrows) compared to adjacent uninvolved mucosa $(\mathrm{N})$.

observed for DcR2. TRAIL protein was completely negative in $27 \%$ of the OSCC cases examined; the remaining OSCC revealed only a few $(<5 \%)$ isolated tumor cells with cytoplasmic staining for TRAIL (Data not shown). TRAIL-R in primary OSCC demonstrated marked interand intratumoral heterogeneity in their staining patterns. DR4 was expressed in $98 \%$ of OSCC (41/42 cases) (IHC score: mean $\pm \mathrm{SD}=2.24 \pm 0.918$; range $0.5-4)$ and $57 \%$

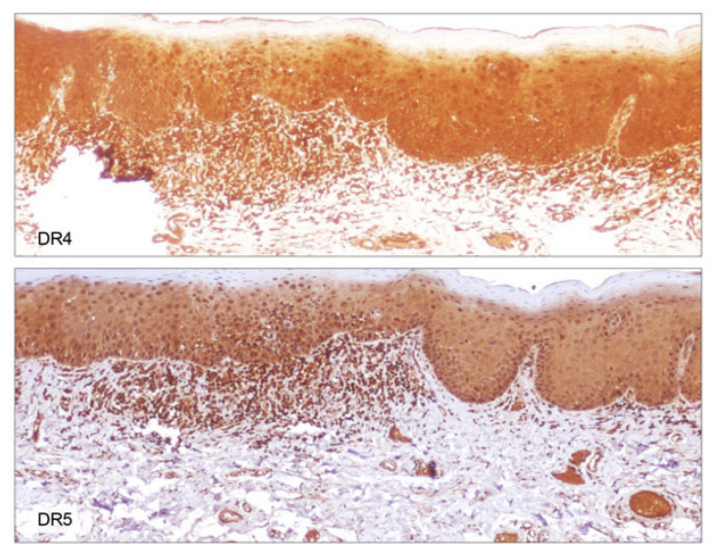

\section{Figure 6}

DR4 and DR5 immunohistochemical staining of the lesion shown in figure $5(\times 100)$. Immunoreactivity for either DR4 (top) or DR5 (bottom) is not altered in dysplasia compared to adjacent uninvolved mucosa. 


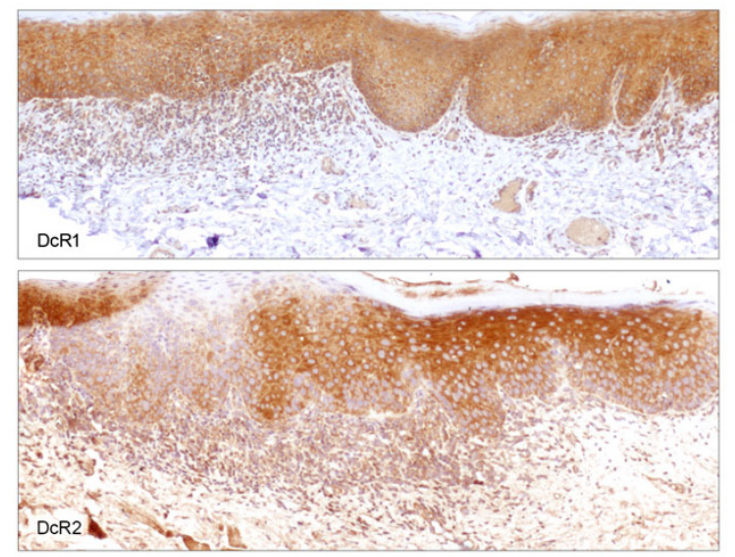

\section{Figure 7}

DcRI and DcR2 immunohistochemical staining of the lesion shown in figure 5 ( $\times 100)$. Immunoreactivity for DcRI (top) is not altered in dysplasia compared to adjacent uninvolved mucosa. Focal loss of DcR2 expression (bottom) is noted in dysplasia compared to adjacent uninvolved mucosa.

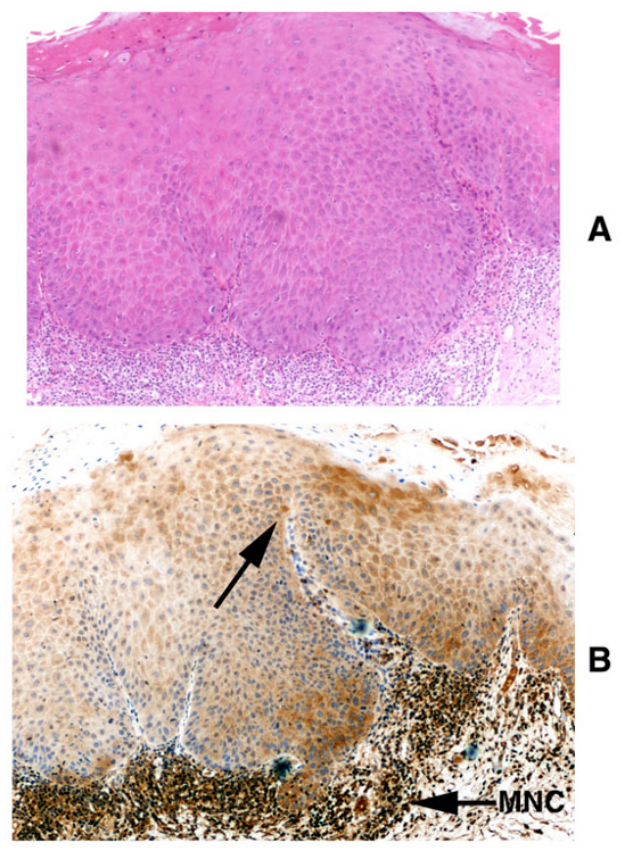

\section{Figure 8}

Loss of TRAIL expression pattern in oral leukoplakia with severe dysplasia. A: Hematoxylin and eosin staining ( $\times 100)$; B: Immunohistochemical staining for TRAIL $(\times 100)$. Note that TRAIL expression is mostly lost in dysplastic epithelium (arrow). In contrast, mononuclear immune cell infiltrate (MNC) associated with dysplasia reveals intense staining for TRAIL.
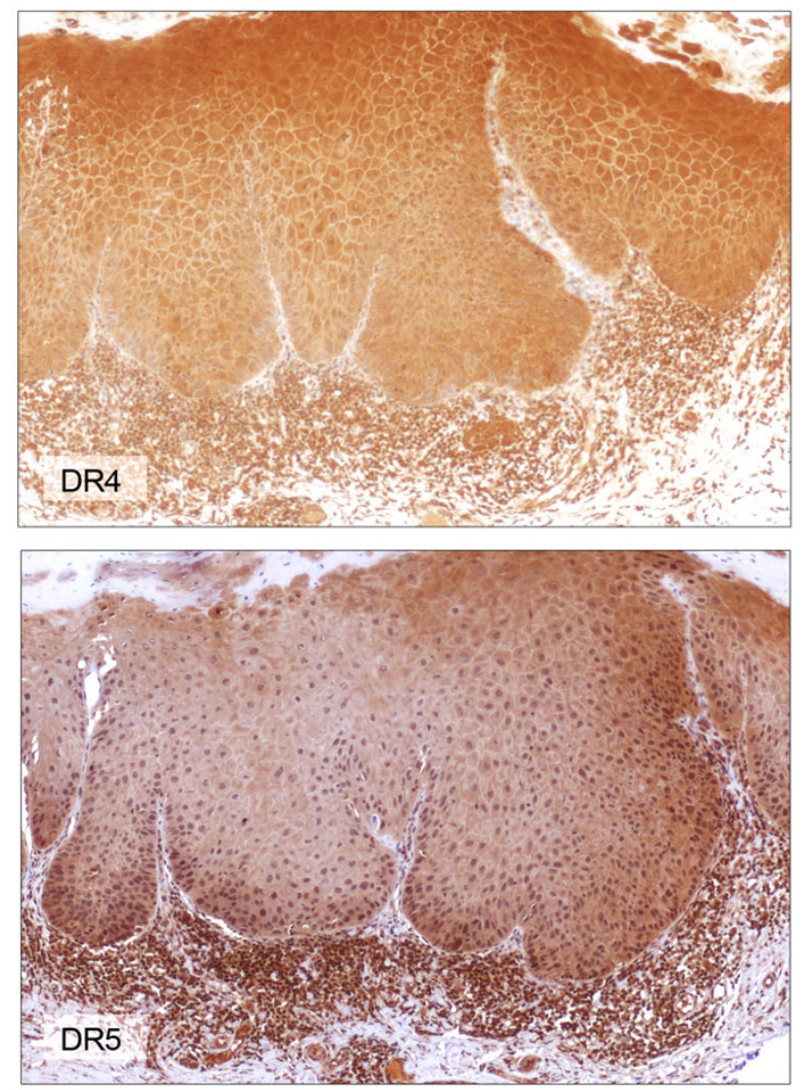

\section{Figure 9}

DR4 and DR5 immunohistochemical staining of the lesion shown in figure $8(\times 100)$. Dysplastic epithelium and associated mononuclear immune cell infiltrate (MNC) demonstrate intense staining for both DR4 and DR5.

of these tumors exhibited high levels of DR4 expression (IHC score $\geq 2$ ) (Figure 11). Thirty-nine of 42 OSCC cases (93\%) were positive for DR5 (IHC score: mean $\pm \mathrm{SD}=$ $1.362 \pm 0.696$; range $0.5-3.2)$ and $21 \%$ of these tumors were high expressors (IHC score $\geq 2$ ) for DR5 (Figure 11). All OSCC were positive for either DR4 or DR5 and none of them were negative for both receptors. Among the TRAIL decoy receptors, DcR1 was expressed in all OSCC cases (IHC score: mean $\pm \mathrm{SD}=2.52 \pm 0.674$; range $1.0-$ 4 ) and $71 \%$ of these cases expressed high levels (IHC score $\geq 2$ ) of DcR1 (Figure 11). On the other hand, DcR2 was positive in $62 \%(26 / 42)$ of OSCC cases (IHC score: mean $\pm \mathrm{SD}=0.628 \pm 0.483$; range $0.5-2.3$ ) but was expressed in high levels only in one case (Figure 11). Expression levels of DR4, DR5, DcR1 and DcR2 in metastatic OSCC were not significantly different from their patient-matched primary tumors (Figure 11).

\section{TRAIL-R expression levels and clinicopathologic parameters}

We examined the relationship between TRAIL-R expression and various prognostic factors. There was no signifi- 

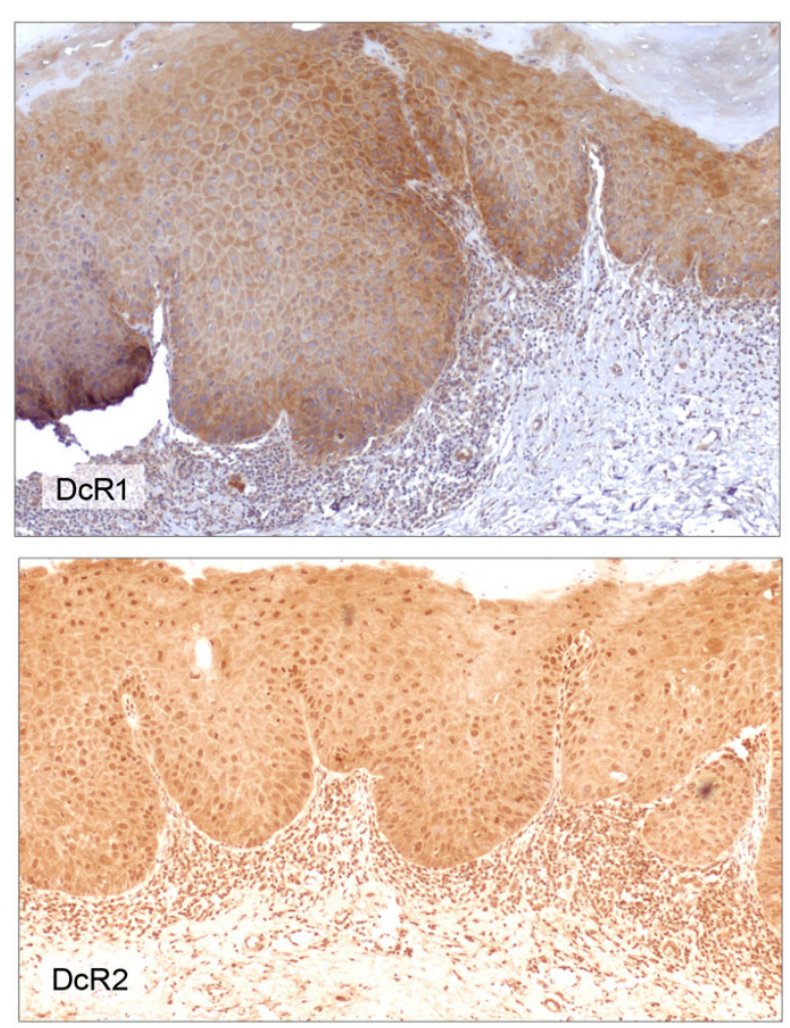

\section{Figure 10}

DcRI and DcR2 immunohistochemical staining of the lesion shown in figure $8(\times 100)$. Dysplastic epithelium and associated mononuclear immune cell infiltrate (MNC) are positive for both DcRI and DcR2.

cant association of either DR4 or DcR1 or DcR2 expression with either tumor size $(\mathrm{T})$ or nodal status $(\mathrm{N})$ or histologic grade of the primary tumor (Table 2). Expression levels of DR5 in primary OSCC correlated positively with tumor size $(p=0.03)$ but failed to show any significant correlation with either nodal status or histologic tumor grade (Table 3).

\section{TRAIL-R expression levels and apoptosis rates in tumor cells and tumor infiltrating lymphocytes (TIL)}

We determined the apoptosis rates of tumor cells and TIL by measuring their cleaved caspase 3 labeling indices $\left(\mathrm{LI}_{\text {Casp }}\right)$ in primary OSCC (Figure 12). The overall $\mathrm{LI}_{\text {Casp }}$ of tumor cells was 3.4/HPF $\left(\mathrm{LI}_{\mathrm{Casp}}-\mathrm{TU}=3.4 \pm 2.6\right.$; range $=0.2$ - 12.2), and $\mathrm{LI}_{\text {Casp }}$ of TIL was 6.9/HPF $\left(\mathrm{LI}_{\mathrm{Casp}}-\mathrm{TIL}=6.9 \pm\right.$ 5.2 ; range $=0.6-25)$. There were no significant associations between the tumor cells or TIL apoptosis rates and tumor size $(\mathrm{T})$ or nodal status $(\mathrm{N})$ (Table 3 ). However, basaloid squamous cell carcinoma, which is a highly aggressive variant of OSCC, exhibited significantly higher
$\mathrm{LI}_{\text {Casp }}$-TIL compared to the conventional OSCC (Table 3). We also examined the correlation between TRAIL and TRAIL-R expression levels and apoptosis rate among tumor cells and tumor infiltrating lymphocytes (Table 3). There was no significant relationship between the expression levels of all four TRAIL-R in tumor cells and their apoptosis rate (Table 3 ). Moreover apoptosis rates of TIL in OSCC did not differ significantly between TRAIL- positive and -negative tumors (Table 3 ).

\section{Discussion}

We and others have demonstrated that OSCC cells are susceptible to TRAIL-induced apoptosis [7,10,33]. A Phase 1 clinical study of TRAIL-R agonist antibody (HGS-ETR1) in patients with advanced solid malignancies including head and neck cancer has proven its safety and biological activity as measured by durable stable disease in these patients [20]. Our study, however, is the first to characterize and compare alterations in TRAIL and TRAIL-R in normal oral epithelia, OPM and OSCC. Our data document the following important findings: 1 . Normal oral epithelia constitutively expressed TRAIL, but its expression was progressively lost in OPM and OSCC. 2. Reduction in DCR2 expression level was noted frequently in OPM and OSCC compared to respective patient-matched uninvolved oral mucosa. 3. Expression levels of DR4, DR5 and DCR1 receptors were not significantly altered in OPM, primary OSCC or metastatic OSCC compared to patientmatched normal oral mucosa. 4. Expression of proapoptotic TRAIL-receptors DR4 and DR5 in OSCC seemed to depend, at least in part, on whether or not these receptors were expressed in their parental oral epithelia. 5. High DR5 expression in primary OSCC correlated significantly with larger tumor size. 6 . There was no significant association between TRAIL-R expression and OSSC histology grade, nodal status, or apoptosis rates of tumor cells and TIL.Loss of TRAIL expression is an early event during oral carcinogenesis

The functional role of TRAIL, which is constitutively expressed in most normal tissues, is poorly understood. Recently, however, TRAIL has been shown to trigger apoptosis in transformed or dysplastic epithelial cells, suggesting a therapeutic potential as a chemopreventive agent against malignant progression of premalignancies $[19,34,35]$. OPM is considered a progenitor of OSCC and represents an intermediate step in the progression from NOM to OSCC [30]. The likelihood for development of OSCC in OPM is generally proportional to its dysplasia grade [30]. Our data revealed that TRAIL, which is expressed in normal oral epithelia, was progressively lost in OPM with increasing dysplasia grade. This was further supported by our microarray data in which TRAIL mRNA levels were 8-fold higher in NOM cells compared to OPM cells. Finally, our immunoblotting data confirmed that TRAIL protein was detectable only in NOM cells not in OPM cells. Similar loss of TRAIL expression during the 

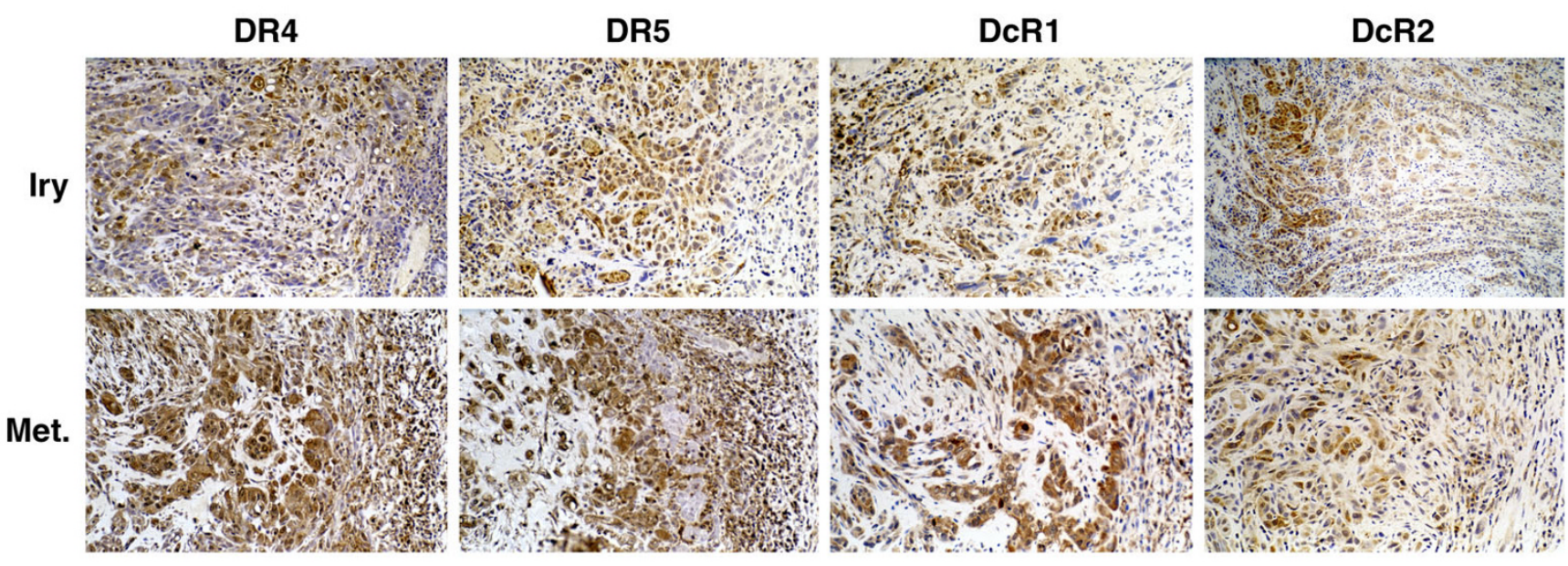

\section{Figure I I}

Expression patterns of TRAIL-R, DR4, DR5, DcRI and DcR2 are not different between primary and synchronous metastatic OSCC. Immunohistochemical expression patterns of TRAIL receptors in primary (Iry) and lymph node metastasis (Met.) of OSCC from the same patient. (× 200).

progression from normal epithelia to malignancy has been reported in skin, esophageal and colon cancers [3638].

The loss of individual TRAIL-R expression in malignant tumors has been attributed to chromosomal gene mutation/deletion (DR4 and DR5) or promotor methylation (DcR1 and DcR2) events [4]. However, gene mutation or promotor methylation is not implicated for the malignancy-specific down-regulation of TRAIL expression. Recent experimental findings indicate that loss of TRAIL expression during malignant transformation is not mediated by genetic aberration but by dysregulation of signal transduction pathways common to various cancers. TNF$\alpha$ increases the susceptibility of breast cancer cells to chemotherapy by up-regulating TRAIL expression by promoter activation [39]. Similarly, retinoids and interferons exert their anticancer activity in breast cancer cells by enhancing TRAIL expression in these cells [40]. Hyperactivation of the phosphatidylinositol 3-kinase (PI-3K)/Akt pathway has been implicated in suppressing TRAIL expression in colon cancer cells [41]. Treatment of colon cancer cells with the PI-3K inhibitor Wortmannin rescues TRAIL expression in these cells and induces enterocytelike differentiation [41]. Interestingly, hyperactivation of PI-3K/AKT pathway via dysregulated EGFR signaling is an important and early event in the pathogenesis of OSCC [42]. Hence, it is plausible that there is a cause-and-effect relationship between dysregulated prosurvival PI-3K/AKT signaling and loss of TRAIL expression in OPM and OSCC.
Interestingly, oral carcinogens such as tobacco smoke frequently inactivate the tumor suppressor gene $p 53$, thus depriving its protective role against oral carcinogeninduced DNA damage [43]. TRAIL-induced apoptosis of transformed/dysplastic cells is independent of $p 53$ status $[34,44]$, hence, TRAIL may act as a substitute guardian against malignant transformation by eliminating transformed cells during the initial genesis OPM. Thus, TRAIL down-regulation may allow clonal expansion of transformed cells by protecting them from apoptosis, thereby increasing the risk of malignant progression.

TRAIL protein detection was mostly negative or only focally positive in isolated tumor cells in both primary and metastatic OSCC tumors, and our Western blot analysis clearly demonstrated the lack of TRAIL protein in primary and metastatic OSCC cell lines. Our microarray data also confirmed low levels of TRAIL mRNA in primary and metastatic OSCC cell lines compared to NOM. Our findings are not, however, in agreement with a previous study reporting the expression of TRAIL protein in primary OSCC tumor specimens and TRAIL mRNA expression in established OSCC cell lines $[24,25]$. That study used RTPCR, which can presumably detect much lower levels of TRAIL mRNA compared to our microarray analysis. Moreover, that study did not compare the TRAIL mRNA levels of OSCC cell lines with NOM to determine significant differences in their respective expression levels. The microarray chip used in our study included three different probe sets for TRAIL which further increased the specificity and reliability of the data. Nevertheless, tumor heterogeneity 
Table 2: Correlation between TRAIL receptor expression levels and clinicopathologic prognosticators in primary OSCC

\begin{tabular}{|c|c|c|c|c|}
\hline Variables & DR4 Mean \pm SD & DR5 Mean \pm SD & DcRI Mean \pm SD & DcR2 Mean \pm SD \\
\hline \multicolumn{5}{|l|}{ Histologic grade } \\
\hline Well differentiated $(n=6)$ & $2.96 \pm 0.53$ & $1.23 \pm 0.71$ & $2.40 \pm 1.05$ & $0.55 \pm 0.38$ \\
\hline Mod. differentiated $(n=19)$ & $2.03 \pm 0.91$ & $1.51 \pm 0.79$ & $2.46 \pm 0.65$ & $0.69 \pm 0.42$ \\
\hline Poorly differentiated $(n=8)$ & $2.15 \pm 0.86$ & $1.01 \pm 0.26$ & $2.61 \pm 0.61$ & $0.80 \pm 0.73$ \\
\hline Basaloid SCC $(n=9)$ & $2.18 \pm 1.05$ & $1.43 \pm 0.70$ & $2.64 \pm 0.54$ & $0.39 \pm 0.36$ \\
\hline$P$ value & 0.189 & 0.366 & 0.864 & 0.305 \\
\hline \multicolumn{5}{|l|}{ Tumor size } \\
\hline $\mathrm{PTI}(\mathrm{n}=14)$ & $2.45 \pm 1.06$ & $1.19 \pm 0.65$ & $2.41 \pm 0.57$ & $0.53 \pm 0.47$ \\
\hline PT2 $(n=23)$ & $2.16 \pm 0.85$ & $1.44 \pm 0.63$ & $2.60 \pm 0.77$ & $0.60 \pm 0.41$ \\
\hline PT3 $(n=2)$ & $2.05 \pm 0.21$ & $2.5 \pm 0.98$ & $2.45 \pm 0.07$ & $0.75 \pm 0.07$ \\
\hline pT4 $(n=3)$ & $1.93 \pm 1.15$ & $2.7 \pm 0.57$ & $2.7 \pm 0.7$ & $1.10 \pm 1.04$ \\
\hline$P$ value & 0.734 & $\underline{0.03}$ & 0.846 & 0.336 \\
\hline \multicolumn{5}{|l|}{ Lymph node status } \\
\hline $\mathrm{pNO}(\mathrm{n}=25)$ & $2.27 \pm 0.88$ & $1.36 \pm 0.79$ & $2.67 \pm 0.75$ & $0.69 \pm 0.55$ \\
\hline $\mathrm{pNI} / 2(\mathrm{n}=17)$ & $2.21 \pm 0.99$ & $1.35 \pm 0.57$ & $2.34 \pm 0.50$ & $0.53 \pm 0.36$ \\
\hline$P$ value & 0.842 & 0.986 & 0.098 & 0.256 \\
\hline
\end{tabular}

Table 3: Correlation between TRAIL/TRAIL-R expression patterns and apoptosis rates of tumor cells and tumor-infiltrating lymphocytes within primary oral squamous cell carcinomas

\begin{tabular}{|c|c|c|}
\hline TRAIL/TRAIL-R & $\mathrm{LI}_{\text {CASP}}-\mathrm{TU}$ Mean $\pm \mathrm{SEM}$ & $\mathrm{LI}_{\mathrm{CASP}}-\mathrm{LY}$ Mean $\pm \mathrm{SEM}$ \\
\hline \multicolumn{3}{|l|}{ TRAIL } \\
\hline Focally positive tumors $(n=31 ; 73 \%)$ & $3.43 \pm 0.5$ & $5.95 \pm 0.74$ \\
\hline Negative tumors $(n=11 ; 27 \%)$ & $3.20 \pm 0.83$ & $10.91 \pm 2.9$ \\
\hline$P$ value & 0.818 & 0.145 \\
\hline \multicolumn{3}{|l|}{ DR4 } \\
\hline High expressors (IHC score $>2 ; n=28 ; 67 \%$ ) & $2.89 \pm 0.47$ & $5.80 \pm 0.8$ \\
\hline Low expressors (IHC score $<2 ; n=14 ; 33 \%)$ & $4.4 \pm 0.93$ & $9.24 \pm 2.2$ \\
\hline$P$ value & 0.11 & 0.07 \\
\hline \multicolumn{3}{|l|}{ DR5 } \\
\hline High expressors (IHC score > 2; $n=9 ; 21 \%$ ) & $2.4 \pm 0.57$ & $7.4 \pm 3.01$ \\
\hline Low expressors (IHC score $<2 ; n=33 ; 79 \%$ ) & $3.61 \pm 0.51$ & $6.73 \pm 0.81$ \\
\hline$P$ value & 0.24 & 0.75 \\
\hline \multicolumn{3}{|l|}{ DcRI } \\
\hline High expressors (IHC score > 2; $\mathrm{n}=36 ; 86 \%$ ) & $3.55 \pm 0.48$ & $6.56 \pm 0.77$ \\
\hline Low expressors (IHC score $<2 ; n=6 ; 14 \%)$ & $3.53 \pm 1.32$ & $8.2 \pm 3.4$ \\
\hline$P$ value & 0.99 & 0.48 \\
\hline \multicolumn{3}{|l|}{ DcR2 } \\
\hline High expressors (IHC score > 2; $n=1 ; 2 \%$ ) & 12.2 & 20.2 \\
\hline Low expressors (IHC score < 2; $n=4 I$; 98\%) & $3.15 \pm 0.37$ & $6.5 \pm 0.78$ \\
\hline$P$ value & $N / A$ & $N / A$ \\
\hline \multicolumn{3}{|l|}{ Histology } \\
\hline Conventional squamous cell carcinoma $(n=33)$ & $2.67 \pm 0.62$ & $2.67 \pm 0.62$ \\
\hline Basaloid squamous cell carcinoma $(n=9)$ & $3.62 \pm 0.51$ & $\mid \mathrm{I} .27 \pm 2.2 \mathrm{I}$ \\
\hline$P$ value & 0.36 & $\underline{0.013}$ \\
\hline
\end{tabular}




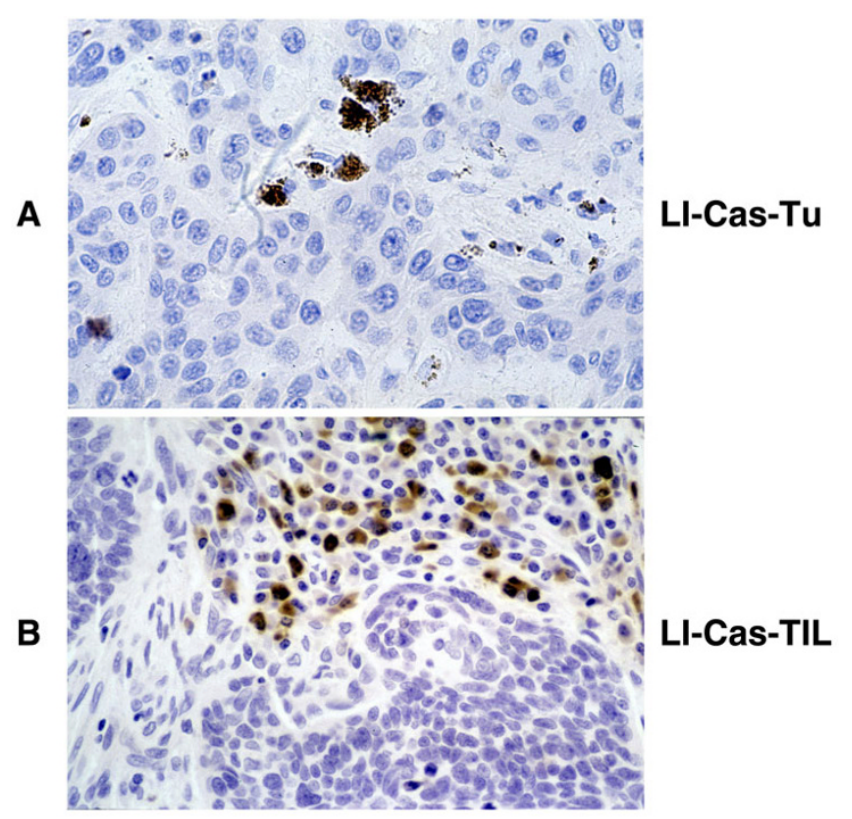

Figure 12

Immunohistochemical staining for cleaved caspase 3 to detect apoptotic cells among tumor cells and tumor-infiltrating lymphocytes. Examples showing the detection apoptotic cells among tumor cells (LI-Cas-Tu)) and TIL (LI-Cas-TIL) based on their immunoreactivity for cleaved caspase- $3(x$ 400).

and the differences in the specificity of the TRAIL antibody used in the two investigations may account for the discrepancies in the OSCC TRAIL expression data.

\section{Expression of DR4, DR5 and DcRI receptors are not significantly altered during oral cancer progression} Relative expression levels of TRAIL death and decoy receptors are critical for exploiting therapeutic possibilities based on TRAIL/TRAIL-R interaction in OPM and OSCC $[7,10,33,45]$. Expression of these three receptors by OSCC seems to depend at least in part on whether or not they are expressed by the parental oral epithelium from which the tumors arose. Moreover, expression of all three receptors in the tumor cells were higher than in adjacent NOM, a feature also reported for melanomas and breast and colon carcinomas [46-48]. In contrast, DcR2 expression was significantly lower in OSCC compared to the adjacent NOM. Loss of DcR2 expression in malignant tumor cells has been attributed to aberrant promotor methylation [49].

DcR1, DR4 and DR5 are very frequently overexpressed in dysplastic oral mucosa, as well as primary and metastatic OSCC tumor specimens. All primary OSCC specimens examined by us expressed either DR4 or DR5 or both at high levels. Among the death-inducing receptors, DR4 was expressed more frequently in OSCC than DR5, as also observed by others in head and neck squamous cell carcinomas [25]. Therefore, it would seem that the DR4-targeted humanized agonist antibody (HGS-ETR1) would be a better choice than the DR5-targeted antibody (HGSETR2) for OSCC clinical trials.

TRAIL death-inducing receptors DR4 and DR5 are considered tumor suppressors because their loss is expected to provide a survival advantage to the tumor cells. Conversely, overexpression of the anti-apoptotic decoy receptors DcR1 and DcR2 is expected to promote malignant progression. Therefore, we evaluated the association between the expression levels of these receptors and certain accepted prognostic indicators such as tumor size, nodal status and histologic tumor grade. Expression levels of these receptors failed to show any significant correlation with either nodal status or tumor grade, and there was no significant association between DR4, DcR1 and DcR2 expression levels and tumor size. However, DR5 expression correlated positively with tumor size. Such an association is in conflict with its proposed pro-apoptotic and tumor-suppressive function yet a similar observation is also made in breast cancers, in which high DR5 expression has correlated with nodal status, tumor size, and poor survival rate [48]. Similarly, high DR5 but not DR4 expression correlated with decreased survival in patients with non-small-cell lung cancers [50]. DR5 expression is induced by DNA damage and the induction is both wildtype $p 53$ dependent and independent [51]. Activation of endogenous NF-kB factors by TNF- $\alpha$ also induces DR5 expression in tumor cells [52]. Thus, anti-apoptotic NF-kB activation may explain the association between increased DR5 expression and larger tumor size.

TRAIL and TRAIL-R expression in OSCC does not influence tumor cell and tumor infiltrating lymphocyte apoptosis rates

Susceptibility of OSCC cells to TRAIL-mediated apoptosis is dependent on their relative expression levels of deathinducing receptors DR4 and DR5 versus decoy receptors DCR1 and DcR2. OSCC expressing high levels of DR4 and/ or DR5 will be more susceptible to apoptosis than tumors expressing low levels of these receptors. Conversely, OSCC expressing high levels of decoy receptors often shows reduced tumor cell apoptosis rates. However, our data did not show any significant difference in the tumor cell apoptosis rates for primary OSCC with high and low levels of DR4 and/or DR5 expression, or for differential expression levels of decoy receptors DcR1 and DcR2.

TIL represent one of the manifestations of host immune response against malignancy [53], and several clinical studies have documented the prognostic significance of 
TIL in various malignancies, including OSCC $[54,55]$. Apoptosis of TIL in OSCC leads to the depletion of lymphocytes and negatively affects their prognosis [54]. This is further supported by our finding that TIL apoptosis rates in basaloid squamous cell carcinomas, a very aggressive variant of OSCC [56,57], were 5-fold higher than in conventional OSCC. However, TRAIL/TRAIL-R expression patterns or tumor cell apoptosis rates were not significantly different between basaloid squamous cell carcinoma and conventional OSCC. Depletion of TIL in malignant tumors is mediated by a counterattack against Fas-bearing lymphocytes by FasL-expressing tumor cells [58]. Therefore, the potential of tumor-cell-derived TRAIL cytotoxicity against TIL has been proposed by some studies [59]. However, our study did not find any significant difference in the TIL apoptosis rate between focal TRAILpositive and TRAIL-negative OSCC.

\section{Conclusion}

Our investigation has shown that TRAIL is constitutively expressed in normal oral mucosa but its expression is gradually lost in oral premalignant and malignant epithelia. OSCC more frequently expresses DcR1, followed by DR4 and DR5. Moreover, expression of DR4, DR5 and DcR1 are up-regulated in premalignant and malignant oral epithelia compared to normal oral epithelium. A partial loss of DcR2 expression is also noted in premalignant and malignant oral epithelia compared to normal oral epithelia, and DR5 expression is significantly associated with larger tumor size. Expression levels of TRAIL receptors show no significant correlation with nodal status and apoptosis rates of tumor cells and TIL.

\section{Abbreviations}

TRAIL, tumor necrosis factor-related apoptosis-inducing ligand; NOM, normal oral mucosa; OPM, oral premalignancies, OSCC, oral squamous cell carcinoma; TIL, tumor-infiltrating lymphocytes; HRP, horseradish peroxidase, LI-Casp, caspase 3 labeling indices.

\section{Competing interests}

The author(s) declare that they have no competing interests.

\section{Authors' contributions}

$\mathrm{NV}$ and WZ planned and designed the studies, analyzed the data and drafted the manuscript. DB performed all immunohistochemical staining. JW performed cell culture, protein, RNA isolation and immunoblotting. JB and SM were involved in pathologic interpretation, sample collection and revising the manuscript. YL assisted in experimental designs and data interpretation methods. All authors read and approved the final manuscript.

\section{Acknowledgements}

This work was supported by NIH/NIDCR grants DEI3I50 (W.Z) \& RO3 DEI5723 (N.V), a Developmental Research Project funded by the University of Texas M.D. Anderson Cancer Center SPORE in Head and Neck Cancer (NV) and by a Fleming and Davenport Award, Texas Medical Center (NV).

\section{References}

I. Kemp TJ, Kim JS, Crist SA, Griffith TS: Induction of necrotic tumor cell death by TRAIL/Apo-2L. Apoptosis 2003, 8(6):587-599.

2. Wajant H, Pfizenmaier K, Scheurich P: TNF-related apoptosis inducing ligand (TRAIL) and its receptors in tumor surveillance and cancer therapy. Apoptosis 2002, 7(5):449-459.

3. Ashkenazi A: Targeting death and decoy receptors of the tumour-necrosis factor superfamily. Nat Rev Cancer 2002, 2(6):420-430.

4. Yagita $\mathrm{H}$, Takeda $\mathrm{K}$, Hayakawa $\mathrm{Y}$, Smyth MJ, Okumura K: TRAIL and its receptors as targets for cancer therapy. Cancer Sci 2004, 95(10):777-783.

5. Griffith TS, Lynch DH: TRAIL: a molecule with multiple receptors and control mechanisms. Curr Opin Immunol 1998, I0(5):559-563.

6. Sheridan JP, Marsters SA, Pitti RM, Gurney A, Skubatch M, Baldwin D, Ramakrishnan L, Gray CL, Baker K, Wood WI, Goddard AD, Godowski P, Ashkenazi A: Control of TRAIL-induced apoptosis by a family of signaling and decoy receptors. Science 1997, 277(5327):818-82I.

7. Vigneswaran N, Wu J, Nagaraj N, Adler-Storthz K, Zacharias W: Differential susceptibility of metastatic and primary oral cancer cells to TRAIL-induced apoptosis. Int J Oncol 2005, 26(I): $103-112$.

8. Zhang L, Fang B: Mechanisms of resistance to TRAIL-induced apoptosis in cancer. Cancer Gene Ther 2005, I 2(3):228-237.

9. Mace TA, Yamane N, Cheng J, Hylander BL, Repasky EA: The potential of the tumor microenvironment to influence Apo2L/ TRAIL induced apoptosis. Immunol Invest 2006, 35(3-4):279-296.

10. Nagaraj NS, Vigneswaran N, Zacharias W: Hypoxia inhibits TRAIL-induced tumor cell apoptosis: Involvement of lysosomal cathepsins. Apoptosis 2007, I 2(I): 125-139.

II. Ashkenazi A, Pai RC, Fong S, Leung S, Lawrence DA, Marsters SA, Blackie C, Chang L, McMurtrey AE, Hebert A, DeForge L, Koumenis IL, Lewis D, Harris L, Bussiere J, Koeppen H, Shahrokh Z, Schwall RH: Safety and antitumor activity of recombinant soluble Apo2 ligand. J Clin Invest 1999, 104(2): I55-162.

12. Walczak H, Miller RE, Ariail K, Gliniak B, Griffith TS, Kubin M, Chin W, Jones J, Woodward A, Le T, Smith C, Smolak P, Goodwin RG, Rauch CT, Schuh JC, Lynch DH: Tumoricidal activity of tumor necrosis factor-related apoptosis-inducing ligand in vivo. Nat Med 1999, 5(2): 157-163.

13. Chinnaiyan AM, Prasad U, Shankar S, Hamstra DA, Shanaiah M, Chenevert TL, Ross BD, Rehemtulla A: Combined effect of tumor necrosis factor-related apoptosis-inducing ligand and ionizing radiation in breast cancer therapy. Proc Natl Acad Sci U S A 2000, 97(4): 1754-1759.

14. Gliniak B, Le T: Tumor necrosis factor-related apoptosisinducing ligand's antitumor activity in vivo is enhanced by the chemotherapeutic agent CPT-II. Cancer Res 1999, 59(24):6153-6158.

15. Marini P, Schmid A, Jendrossek V, Faltin H, Daniel PT, Budach W, Belka C: Irradiation specifically sensitises solid tumour cell lines to TRAIL mediated apoptosis. BMC Cancer 2005, 5:5.

16. Marini P, Denzinger S, Schiller D, Kauder S, Welz S, Humphreys R, Daniel PT, Jendrossek V, Budach W, Belka C: Combined treatment of colorectal tumours with agonistic TRAIL receptor antibodies HGS-ETRI and HGS-ETR2 and radiotherapy: enhanced effects in vitro and dose-dependent growth delay in vivo. Oncogene 2006, 25(37):5I45-5I54.

17. Pukac L, Kanakaraj P, Humphreys R, Alderson R, Bloom M, Sung C, Riccobene T, Johnson R, Fiscella M, Mahoney A, Carrell J, Boyd E, Yao $X T$, Zhang L, Zhong L, von Kerczek A, Shepard L, Vaughan T, Edwards B, Dobson C, Salcedo T, Albert V: HGS-ETRI, a fully human TRAIL-receptor I monoclonal antibody, induces cell 
death in multiple tumour types in vitro and in vivo. $\mathrm{Br}$ J Cancer 2005, 92(8): |430-|44|.

18. Shankar S, Srivastava RK: Enhancement of therapeutic potential of TRAIL by cancer chemotherapy and irradiation: mechanisms and clinical implications. Drug Resist Updat 2004, 7(2): $139-156$.

19. Finnberg N, El-Deiry WS: Selective TRAIL-induced apoptosis in dysplastic neoplasia of the colon may lead to new neoadjuvant or adjuvant therapies. Clin Cancer Res 2006, I 2(I 4 Pt I):4132-4I36

20. Anonymous: Human Genome Sciences Completes Patient Enrollment in A Phase 2 Clinical Trial of HGS-ETRI for the Treatment of Non-Small Cell Lung Cancer. 2005 [http:// www.prnewswire.com/cgi-bin/stories.pl!ACCT $=104 \& S T O R Y=1$ www/story/I I-30-2004/00025546/5\&EDATE=].

21. Takeda K, Hayakawa Y, Smyth MJ, Kayagaki N, Yamaguchi N, Kakuta $\mathrm{S}$, Iwakura $\mathrm{Y}$, Yagita H, Okumura K: Involvement of tumor necrosis factor-related apoptosis-inducing ligand in surveillance of tumor metastasis by liver natural killer cells. Nat Med 200I, 7(I):94-100.

22. Seki N, Hayakawa Y, Brooks AD, Wine J, Wiltrout RH, Yagita H, Tanner JE, Smyth MJ, Sayers TJ: Tumor necrosis factor-related apoptosis-inducing ligand-mediated apoptosis is an important endogenous mechanism for resistance to liver metastases in murine renal cancer. Cancer Res 2003, 63(I):207-2/3.

23. Rowinsky EK: Targeted induction of apoptosis in cancer management: the emerging role of tumor necrosis factor-related apoptosis-inducing ligand receptor activating agents. J Clin Oncol 2005, 23(36):9394-9407.

24. Fukuda M, Hamao A, Tanaka A, Kitada M, Suzuki S, Kusama K, Sakashita $\mathrm{H}$ : Tumor necrosis factor-related apoptosis-inducing ligand (TRAIL/APO2L) and its receptors expression in human squamous cell carcinoma of the oral cavity. Oncol Rep 2003 , I0(5): III3-III9.

25. Teng MS, Brandwein-Gensler MS, Teixeira MS, Martignetti JA, Duffey DC: A study of TRAIL receptors in squamous cell carcinoma of the head and neck. Arch Otolaryngol Head Neck Surg 2005, I 3 I(5):407-4 I2

26. Sacks PG: Cell, tissue and organ culture as in vitro models to study the biology of squamous cell carcinomas of the head and neck. Cancer Metastasis Rev 1996, I5(I):27-5I

27. Vigneswaran N, Beckers S, Waigel S, Mensah J, Wu J, Mo J, Fleisher $\mathrm{KE}$, Bouquot J, Sacks PG, Zacharias W: Increased EMMPRIN (CD 147) expression during oral carcinogenesis. Exp Mol Pathol 2006, 80(2):147-159.

28. Vigneswaran N, Wu J, Sacks P, Gilcrease M, Zacharias W: Microarray gene expression profiling of cell lines from primary and metastatic tongue squamous cell carcinoma: possible insights from emerging technology. J Oral Pathol Med 2005, 34(2):77-86

29. Park NH, Gujuluva CN, Baek JH, Cherrick HM, Shin KH, Min BM: Combined oral carcinogenicity of HPV-16 and benzo(a)pyrene: an in vitro multistep carcinogenesis model. Oncogene 1995, IO(I I):2 I45-2I53.

30. Pindborg JJ, Reichart PA, Smith CJ, der. WJ: Histological Typing of Cancer and Precancer of the Oral Mucosa WHO. 2nd edition. New York , Springer; 1997

31. Gown AM, Willingham MC: Improved detection of apoptotic cells in archival paraffin sections: immunohistochemistry using antibodies to cleaved caspase 3. J Histochem Cytochem 2002, 50(4):449-454.

32. Vigneswaran N, Zhao W, Dassanayake A, Muller S, Miller DM, Zacharias W: Variable expression of cathepsin $B$ and $D$ correlates with highly invasive and metastatic phenotype of oral cancer. Hum Pathol 2000, 3 I (8):931-937.

33. Nagaraj NS, Vigneswaran N, Zacharias W: Cathepsin B mediates TRAIL-induced apoptosis in oral cancer cells. J Cancer Res Clin Oncol 2006, 132(3): I7I-183.

34. Jalving $M$, de Jong $S$, Koornstra J], Boersma-van Ek W, Zwart $N$, Wesseling J, de Vries EG, Kleibeuker JH: TRAIL induces apoptosis in human colorectal adenoma cell lines and human colorectal adenomas. Clin Cancer Res 2006, I 2(I4 Pt I):4350-4356.

35. Lu X, Arbiser JL, West J, Hoedt-Miller M, Sheridan A, Govindarajan B, Harral JW, Rodman DM, Fouty B: Tumor necrosis factorrelated apoptosis-inducing ligand can induce apoptosis in subsets of premalignant cells. Am 」 Pathol 2004, 165(5): 1613-1620.

36. Popnikolov NK, Gatalica Z, Adegboyega PA, Norris BA, Pasricha PJ: Downregulation of TNF-related apoptosis-inducing ligand (TRAIL)/Apo2L in Barrett's esophagus with dysplasia and adenocarcinoma. Appl Immunohistochem Mol Morphol 2006, I4(2): $161-165$

37. Stander S, Schwarz T: Tumor necrosis factor-related apoptosisinducing ligand (TRAIL) is expressed in normal skin and cutaneous inflammatory diseases, but not in chronically UVexposed skin and non-melanoma skin cancer. Am J Dermatopathol 2005, 27(2): || 6-|2|.

38. Strater J, Hinz U, Walczak H, Mechtersheimer G, Koretz K, Herfarth C, Moller P, Lehnert T: Expression of TRAIL and TRAIL receptors in colon carcinoma: TRAIL-RI is an independent prognostic parameter. Clin Cancer Res 2002, 8( I 2):3734-3740.

39. Xu J, Zhou JY, Wu GS: Tumor necrosis factor-related apoptosis-inducing ligand is required for tumor necrosis factor alpha-mediated sensitization of human breast cancer cells to chemotherapy. Cancer Res 2006, 66(20): 10092-10099.

40. Clarke N, Jimenez-Lara AM, Voltz E, Gronemeyer H: Tumor suppressor IRF-I mediates retinoid and interferon anticancer signaling to death ligand TRAIL. Embo J 2004, 23(I5):305I-3060.

4I. Wang Q, Wang X, Hernandez A, Hellmich MR, Gatalica Z, Evers BM: Regulation of TRAIL expression by the phosphatidylinositol 3-kinase/Akt/GSK-3 pathway in human colon cancer cells. J Biol Chem 2002, 277(39):36602-36610.

42. Kalyankrishna S, Grandis JR: Epidermal growth factor receptor biology in head and neck cancer. J Clin Oncol 2006, 24(I 7):2666-2672.

43. Lazarus P, Sheikh SN, Ren Q, Schantz SP, Stern JC, Richie JP Jr., Park $J Y: p 53$, but not p 16 mutations in oral squamous cell carcinomas are associated with specific CYPIAI and GSTMI polymorphic genotypes and patient tobacco use. Carcinogenesis 1998, 19(3):509-514.

44. El-Deiry WS: Insights into cancer therapeutic design based on p53 and TRAIL receptor signaling. Cell Death Differ 200I, 8(II): 1066-1075

45. Winn DM: Epidemiology of cancer and other systemic effects associated with the use of smokeless tobacco. Adv Dent Res I997, I I(3):3|3-32|

46. Koornstra J], Kleibeuker JH, van Geelen CM, Rijcken FE, Hollema $\mathrm{H}$, de Vries EG, de Jong S: Expression of TRAIL (TNF-related apoptosis-inducing ligand) and its receptors in normal colonic mucosa, adenomas, and carcinomas. J Pathol 2003, 200(3):327-335.

47. McCarthy MM, DiVito KA, Sznol M, Kovacs D, Halaban R, Berger AJ, Flaherty KT, Camp RL, Lazova R, Rimm DL, Kluger HM: Expression of tumor necrosis factor--related apoptosis-inducing ligand receptors $I$ and 2 in melanoma. Clin Cancer Res 2006, I 2(I 2):3856-3863.

48. McCarthy MM, Sznol M, DiVito KA, Camp RL, Rimm DL, Kluger HM Evaluating the expression and prognostic value of TRAIL-R I and TRAIL-R2 in breast cancer. Clin Cancer Res 2005, I I(I4):5 I88-5I 94.

49. Shivapurkar N, Toyooka S, Toyooka KO, Reddy J, Miyajima K, Suzuki M, Shigematsu H, Takahashi T, Parikh G, Pass HI, Chaudhary PM, Gazdar AF: Aberrant methylation of trail decoy receptor genes is frequent in multiple tumor types. Int J Cancer 2004, 109(5):786-792.

50. Spierings DC, de Vries EG, Timens W, Groen HJ, Boezen HM, de Jong S: Expression of TRAIL and TRAIL death receptors in stage III non-small cell lung cancer tumors. Clin Cancer Res 2003, 9(9):3397-3405.

5I. Sheikh MS, Burns TF, Huang Y, Wu GS, Amundson S, Brooks KS, Fornace AJ Jr., el-Deiry WS: p53-dependent and -independent regulation of the death receptor KILLER/DR5 gene expression in response to genotoxic stress and tumor necrosis factor alpha. Cancer Res 1998, 58(8):1593-1598.

52. Ravi R, Bedi GC, Engstrom LW, Zeng Q, Mookerjee B, Gelinas C, Fuchs EJ, Bedi A: Regulation of death receptor expression and TRAIL/Apo2L-induced apoptosis by NF-kappaB. Nat Cell Biol 2001, 3(4):409-416. 
53. Frey $A B$, Monu N: Effector-phase tolerance: another mechanism of how cancer escapes antitumor immune response. J Leukoc Biol 2006, 79(4):652-662.

54. Reichert TE, Strauss L, Wagner EM, Gooding W, Whiteside TL: Signaling abnormalities, apoptosis, and reduced proliferation of circulating and tumor-infiltrating lymphocytes in patients with oral carcinoma. Clin Cancer Res 2002, 8(I 0):3|37-3|45.

55. Koyama S: Differential expression of intracellular apoptotic signaling molecules in tumor and tumor-infiltrating lymphocytes during development of invasion and/or metastasis of gastric carcinoma. Dig Dis Sci 2003, 48(I 2):2290-2300.

56. Barnes L, Ferlito A, Altavilla G, MacMillan C, Rinaldo A, Doglioni C: Basaloid squamous cell carcinoma of the head and neck: clinicopathological features and differential diagnosis. Ann Otol Rhinol Laryngol 1996, 105(I):75-82.

57. Altavilla G, Mannara GM, Rinaldo A, Ferlito A: Basaloid squamous cell carcinoma of oral cavity and oropharynx. ORL J Otorhinolaryngol Relat Spec 1999, 61(3):169-173.

58. O'Connell J, O'Sullivan GC, Collins JK, Shanahan F: The Fas counterattack: Fas-mediated $\mathrm{T}$ cell killing by colon cancer cells expressing Fas ligand. J Exp Med 1996, 184(3): 1075-1082.

59. Koyama S, Koike N, Adachi S: Expression of TNF-related apoptosis-inducing ligand (TRAIL) and its receptors in gastric carcinoma and tumor-infiltrating lymphocytes: a possible mechanism of immune evasion of the tumor. J Cancer Res Clin Oncol 2002, I 28(2):73-79.

\section{Pre-publication history}

The pre-publication history for this paper can be accessed here:

http://www.biomedcentral.com/1471-2407/7/108/pre pub

Publish with Biomed Central and every scientist can read your work free of charge

"BioMed Central will be the most significant development for disseminating the results of biomedical research in our lifetime. "

Sir Paul Nurse, Cancer Research UK

Your research papers will be:

- available free of charge to the entire biomedical community

- peer reviewed and published immediately upon acceptance

- cited in PubMed and archived on PubMed Central

- yours - you keep the copyright 